\title{
IMPLEMENTASI KEBIJAKAN \\ SISTEM APLIKASI PELAYANAN KEPEGAWAIAN (SAPK) \\ DI BADAN KEPEGAWAIAN DAN PENGEMBANGAN SUMBER DAYA MANUSIA KABUPATEN FAKFAK PROVINSI PAPUA BARAT
}

\author{
Oleh \\ Muhammad Fandy Asyik ${ }^{1}$, \\ I Nyoman Sumaryadi ${ }^{2}$, Deti Mulyati ${ }^{3}$ \\ 1) Badan Kepegawaian dan Pengembangan Sumber Daya Manusia (BKPSDM) Kabupaten Fakfak \\ Program Magister Terapan Studi Pemerintahan Daerah Institut Pemerintahan Dalam Negeri \\ muhammadfandyasyik@gmail.com \\ ${ }^{2,3)}$ Institut Pemerintahan Dalam Negeri
}

\begin{abstract}
$T$ he Personnel Service Application System (SAPK) is an information technology-based personnel service that is connected online and is integrated for use by central and local government agencies so that it will improve services in the staffing sector in a transparent and objective manner. BKPSDM Fakfak Regency has implemented this system to speed up the process of staffing services in accordance with Perka BKN No. 20 of 2008 covering procurement, promotion, retirement and data rejuvenation.

This research is qualitative in nature. Data collection techniques are carried out through semi-structured interviews using interview guidelines, observation (observation) and documentation. The selection of informants is done by purposive sampling, namely the selection of informants with the consideration that the informants know what will be studied and the data analysis technique used 1). Data Reduction (Data reduction data), 2). Data Presentation (Data Displai) and 3). Conclusion Drawing/Verivication (Decision Making/Verification).

The results of this study indicate that the implementation of the SAPK Policy in the Fakfak Regency Government has been running but has not been optimal. For procurement services, NIP frontline and pension services have been well implemented, but promotion has not had the expected impact. Civil servants who are promoted to receive SK Kenpat exceed the deadline for the Kenpat period. Likewise, data rejuvenation, there are still civil servants whose SAPK data, staffing DUK data do not match the real thing, thus slowing down the service process.

Inhibiting factors in the implementation of SAPK include: the unavailability of resources and personnel who have expertise as personnel analysis to validate data, and the internet network is experiencing disruption. Meanwhile, the driving factors include the communication factor: the existence of a written policy and the clarity of the message delivery. resource factors: the availability of staff resources, the ability of the staff as computer operators, and all accept the SAPK policy. As well as efforts to optimize the implementation of the SAPK policy include: Socialization in the form of meetings. Includes personnel analyst training staff and all personnel who operate SAPK.
\end{abstract}

Keywords: SAPK, policy implementation 


\begin{abstract}
Abstrak
istem Aplikasi Pelayanan Kepegawaian (SAPK) merupakan pelayanan kepegawaian berbasis teknologi informasi yang terkoneksi secara online dan terintegrasi untuk digunakan oleh instansi pusat maupun pemerintah daerah sehingga akan meningkatkan pelayanan di bidang kepegawaian secara transparan dan objektif. BKPSDM Kabupaten Fakfak telah menerapkan sistem ini untuk mempercepat proses pelayanan kepegawaian sesuai dengan Perka BKN No. 20 Tahun 2008 meliputi pengadaan, kenaikan pangkat, pensiun dan peremajaan data.

Penelitian ini bersifat kualitatif Teknik pengumpulan data yang dilakukan melalui wawancara semi struktur dengan menggunakan pedoman wawancara, pengamatan (observasi) dan dokumentasi. Pemilihan informan dilakukan dengan cara Purposif samplingyaitu pemilihan informan dengan pertimbangan bahwa informan mengetahui hal yang akan diteliti dan Teknik analisis data yang digunakan 1). Reduksi Data (Data Data reduksi), 2). Penyajian Data (Data Displai) dan 3). Conclusion Drawing/Verivication (Pengambilan Keputusan/Verifikasi).

Hasil penelitian ini menunjukkan bahwa Implementasi Kebijakan SAPK di Pemerintah Kabupaten Fakfak telah berjalan tetapi belum optimal. Untuk pelayanan Pengadaan, Penetapan NIP dan Pelayanan pensiun sudah terimplementasi dengan baik, akan tetapi kenaikan pangkat belum memberikan dampak sebagaimana yang diharapkan. PNS yang naik pangkat menerima SK Kenpat-nya melebihi batas waktu periode Kenpat. Begitupun peremajaan data, masih terdapat PNS yang data SAPK, data DUK kepegawaiannya tidak sesuai dengan yang sebenarnya sehingga memperlambat proses pelayanannya.

Faktor penghambat dalam implementasi SAPK meliputi: belum tersedianya sumber daya dan personel yang memiliki keahlian sebagai analisis kepegawaian untuk memvalidasi data, dan jaringan internet yang mengalami gangguan. Sedangkan Faktor pendukung meliputi Faktor Komunikasi: adanya kebijakan secara tertulis dan adanya kejelasan dalam penyampaian pesan. faktor sumber daya: tersedianya sumber daya staf, kemampuan staf sebagai sebagai operator Komputer, dan semua bersikap menerima kebijakan SAPK. Serta Upaya dalam mengoptimalkan implementasi kebijakan SAPK meliputi: Sosialisasi berupa Rapat. Mengikutsertakan staf Diklat analis kepegawaian dan semua personel yang mengoperasikan SAPK.
\end{abstract}

Kata kunci: SAPK, implementasi kebijakan

\section{PENDAHULUAN}

I ndonesia saat ini sedang mengalami inovasi kehidupan berbangsa dan bernegara secara mendasar sehingga bangsa indonesia dihadapkan pada perubahan-perubahan. Pada era globalisasi ini, masyarakat di Indonesia tidak dapat melawan derasnya perubahan yang terjadi sebagai akibatnya kemajuan teknologi informasi, telekomunikasi, tatanan ekonomi dunia yang mengarah pada pasar bebas, serta tingkat efisiensi dan kompetitif yang baik di berbagai bidang kehidupan. Saat ini penguasaan teknologi informasi dan komunikasi sangatlah penting, terutama dalam upaya meningkatkan produktivitas dan daya saing di pasar global.
Perkembangan teknologi informasi yang semakin pesat mendorong pemanfaatannya dalam berbagai bidang. Teknologi informasi memiliki peranan penting dalam mewujudkan perubahan cara kerja yang memudahkan manusia untuk menyelesaikan pekerjaannya. Sejalan dengan pengertian tersebut di atas, Sutarman menerangkan dalam bukunya bahwa ${ }^{1}$ :

"Information Technology Association of America (ITAA) menjelaskan bahwa, teknologi informasi adalah suatu studi, perancangan, pengembangan, implementasi, dukungan atau manajemen sistem informasi berbasis

1 Sutarman 2009. Pengantar Teknologi Informasi. Jakarta: Bumi Aksara 
komputer, khususnya aplikasi perangkat lunak dan perangkat keras komputer".

Sistem Pemerintahan di Indonesia sangat berpengaruh dengan era globalisasi karena dapat memengaruhi keamanan dan ketahanan nasional serta sosial dan politik. Indonesia juga menerapkan sistem pemerintahan yang terbuka di mana sistem pemerintah Indonesia menampung setiap paham, masukan, pengaruh dari luar (globalisasi). Pemerintah adalah pengurus harian dari suatu negara merupakan keseluruhan dari jabatan-jabatan dalam suatu negara yang mempunyai tugas dan wewenang politik negara dan pemerintah. Pemerintah dalam suatu negara mempunyai wewenang terhadap suatu urusan yang berada dalam lingkup hukum publik. ${ }^{2}$ Adapun fungsi pemerintahan adalah:

1) Fungsi Layanan, Fungsi layanan ini dilakukan secara prima dalam rangka melayani kebutuhan masyarakat tanpa membeda-bedakan atau diskriminatif dalam melaksanakan pelayanan karena setiap masyarakat memiliki hak yang sama dalam menerima pelayanan;

2) Fungsi Pengaturan, fungsi pengaturan ini tidak ditekankan atau ditujukan kepada masyarakat melainkan pada pemerintah itu sendiriartinyabahwa dalam membuat peraturan pemerintah dibatasi agar tidak terlalu mengintervensi (campur tangan) masyarakat;

3) Fungsi Pemberdayaan, fungsi pemberdayaan ini dijalankan oleh pemerintah sebagai pemberdayaan kepada masyarakat di mana pemerintah berfungsi sebagai fasilitator dan juga motivator dalam pemberdayaan kepada masyarakat.

4) Fungsi Pembangunan, Pemerintah harus berfungsi sebagai pemacu pembangunan

2 https://acehprov.go.id/directory/read/406/menjadi-pemerintahan-yang-informatif-melalui-teknologi.html di wilayahnya, di mana pembangunan ini mencakup segala aspek kehidupan tidak hanya fisik tapi juga mental spiritual. ${ }^{3}$

Dalam mencapai fungsi-fungsi tersebut di atas, diperlukan aparatur yang profesional, bebas dari intervensi politik, bersih dari praktik korupsi, kolusi dan nepotisme, serta mampu menyelenggarakan pelayanan publik bagi masyarakat dan mampu menjalankan peran sebagai perekat persatuan dan kesatuan bangsa berdasarkan Pancasila dan UUD 1945. Selanjutnya dalam mewujudkan aparatur yang mampu melaksanakan tugas pelayanan umum, tugas pemerintahan, dan tugas pembangunan yang baik tentu disesuaikan dengan kualifikasi, kompetensi, dan kinerja yang dimiliki dalam pelaksanaan tugasnya masing-masing dalam rangka pencapaian pembangunan nasional.

Pemanfaatan dan pengembangan modal teknologi khususnya teknologi komunikasi informasi dalam proses pemerintahan dimaksudkan agar dapat meningkatkan efisiensi, efektivitas, transparansi dan akuntabilitas penyelenggaraan pemerintahan. Pemerintah harus mampu memanfaatkan kemajuan teknologi informasi untuk meningkatkan kemampuan mengolah, mengelola, menyalurkan dan mendistribusikan informasi dan pelayanan publik.

Kebijakan pemerintah tentang implementasi e-government 2018 ini menekankan untuk menggunakan informasi teknologi di instansi pemerintah pusat maupun daerah yang lebih komprehensif dan terintegrasi. Demikian hanya di bidang kepegawaian, pemanfaatan teknologi informasi bertujuan untuk meningkatkan efektivitas dan efisiensi dalam bidang pengolahan data dan pengolahan informasi kepegawaian, sehingga mampu memberikan pelayanan kepegawaian yang lebih baik, transparansi dan akuntabel.

3 Haryanto dkk, 1997. Pemerintah. Jakarta. Rineka Cipta 
Berdasarkan Peraturan Kepala BKN No. 20 Tahun 2008 tentang Pedoman Pemanfaatan Sistem Aplikasi Pelayanan Kepegawaian, Proses Pemberian Nomor Induk Pegawai (NIP), pemberian persetujuan/pertimbangan teknis kenaikan pangkat PNS penetapan keputusan pensiun PNS dan peremajaan data kepegawaian PNS dilakukan dengan menggunakan sistem aplikasi komputer yang terintegrasi antara BKN, Kantor Regional BKN dan Instansi Pemerintah Pusat dan Daerah. Sistem aplikasi yang digunakan ini adalah Sistem Aplikasi Pelayanan Kepegawaian (SAPK).

Tabel 1. Wilayah kerja Kantor Regional XIV BKN Manokwari tahun 2016

\begin{tabular}{cl}
\hline No & \multicolumn{1}{c}{ Nama Kantor Regional } \\
\hline 1. & Kantor Regional I BKN Yogyakarta \\
2. & Kantor Regional II BKN Surabaya \\
3. & Kantor Regional III BKN Bandung \\
4. & Kantor Regional IV BKN Makassar \\
5. & Kantor Regional V BKN Jakarta \\
6. & Kantor Regional VI BKN Medan \\
7. & Kantor Regional VII BKN Palembang \\
8. & Kantor Regional VIII BKN Banjarmasin \\
9. & Kantor Regionl IX BKN Jayapura \\
10. & Kantor Regional X BKN Denpasar \\
11. & Kantor Regional XI BKN Manado \\
12. & Kantor Regional XII BKN Pekanbaru \\
13. & Kantor Regional XIII BKN Aceh \\
14. & Kantor Regional XIV BKN Manokwari \\
\hline
\end{tabular}

Sumber: website bkn go.id, Februari 2016

Untuk meningkatkan dan memperlancar serta mendekatkan pelayanan kepada PNS di daerah yang jumlahnya semakin bertambah, maka Badan Kepegawaian Negara membentuk kantor regional, di mana setiap kantor regional melayani sejumlah provinsi dan kabupaten/kota yang masuk dalam wilayah kerjanya. Berdasarkan data yang diambil dari website bkn.go.id, sampai bulan Januari 2016 Badan Kepegawaian Negara telah membentuk 14 kantor regional untuk melayani PNS di seluruh Indonesia.
Adapun kantor regional yang telah dibentuk sebagaimana terlihat pada tabel 1 .

Badan Kepegawaian dan Pengembangan Sumber daya Manusia (BKPSDM) Kabupaten Fakfak merupakan salah satu dari stakeholders BKN Kantor Regional XIV Manokwari memberikan pelayanan kepegawaian kepada Pegawai Negeri Sipil di Lingkungan Pemerintah Kabupaten Fakfak. Adapun Jumlah Pegawai Negeri Sipil di Lingkungan Pemerintah Kabupaten Fakfak 4 tahun terakhir 2017 s.d. 2020 dapat dilihat pada tabel 2 berikut.

Tabel 2. Jumlah PNS Pemerintah Kabupaten Fakfak tahun 2017-2020

\begin{tabular}{ccc}
\hline No & Tahun & Jumlah PNS \\
\hline 1. & 2017 & 3.865 \\
2. & 2018 & 3.972 \\
3. & 2019 & 3.898 \\
4. & 2020 & 4.013 \\
\hline
\end{tabular}

Sumber: BKPSDM Kabupaten Fakfak tahun 2020.

Dari tabel 2 terlihat bahwa jumlah PNS di Lingkungan Pemerintah Kabupaten Fakfak pada 2017 adalah 3.865 pada 2018 Naik menjadi 3.972, kemudian turun lagi pada 2019 menjadi 3.898, penurunan ini dikarenakan beberapa PNS yang memasuki masa pensiun, dan mutasi keluar PNS oleh pemerintah pada 2018 dan 2020. Selain itu penurunan ini juga disebabkan dimulainya pengisian Organisasi Perangkat Daerah di lingkungan Provinsi Papua Barat.

SAPK adalah salah satu bentuk proses transformasi menuju e-government yang harus dilaksanakan, karena melalui proses transformasi tersebut pemerintah dapat mengoptimalisasikan pemanfaatankemajuan teknologi informasi untuk mengeliminasi sekat-sekat organisasi birokrasi, serta membentuk jaringan sistem manajemen dan proses kerja yang memungkinkan instansi-instansi pemerintah bekerja secara 
terpadu untuk menyederhanakan akses ke semua informasi dan layanan publik yang harus disediakan oleh pemerintah. Proses pelayanan kepegawaian pada SAPK antara lain meliputi penetapan NIP, pencetakan SK pengangkatan CPNS, pemberian nota persetujuan/pertimbangan teknis kenaikan pangkat, pencetakan SK Kenaikan Pangkat, penetapan dan pencetakan surat.

Adanya aplikasi SAPK merupakan salah satu langkah yang harus mendapat prioritas yakni pembenahan manajemen informasi sistem, akurasi data PNS di bidang manajemen kepegawaian yang terintegrasi dengan peningkatan kualitas sumber daya manusia khususnya di bidang spesialisasi informasi.

Adapun tujuan penerapan SAPK antara lain sebagai berikut.

1. Adanya standarisasi sistem informasi kepegawaian berbasis informasi teknologi yang terintegrasi sebagai media dalam pelayanan, pengawasan, pengendalian administrasi kepegawaian.

2. Tersedianya database kepegawaian sebagai media informasi sharing bagi instansi dan stakeholders sesuai dengan kebutuhan.

3. Tersedianya data dan informasi yang up to date dengan cepat dan akurat.

4. Menghilangkan duplikasi sistem dan data

5. Meningkatkan pelayanan kepegawaian bagi pegawai negeri sipil.

6. Penerapan good governance.

7. Meningkatkan kerja sama antarinstansi pemerintah dan stakeholders untuk mencapai efisiensi dan efektivitas berkaitan dengan manajemen kepegawaian. ${ }^{4}$

4 https://id.scribd.com/document/82400072/Data-Dan-Informasi

\section{Rumusan Masalah}

Berdasarkan identifikasi masalah di atas maka rumusan masalah sebagai berikut.

1. Bagaimanakah Implementasi Kebijakan Perka BKN No. 20 Tahun 2008 Sistem Aplikasi Pelayanan Kepegawaian (SAPK) di BKPSDM Kabupaten Fakfak?

2. Apa saja faktor pendukung dan penghambat Implementasi Kebijakan Sistem Aplikasi Pelayanan Kepegawaian (SAPK) di BKPSDM Kabupaten Fakfak?

3. Apa saja upaya yang dilakukan BKPSDM Kabupaten Fakfak untuk mengoptimalkan SAPK sebagai aplikasi Pengadaan, kenaikan pangkat, mutasi, dan pensiun PNS di Kabupaten Fakfak?

\section{METODE PENELITIAN}

Penelitian ini merupakan penelitian yang menggunakan pendekatan kualitatif dengan metode deskriptif di mana pengumpulan data dan analisis.

Penelitian ini menggunakan landasan teori Implementasi Kebijakan Edwards III dengan menggunakan Teknik wawancara, telaah dokumen, dan observasi dengan menggunakan teknik purposive sampling.

\section{HASIL PENELITIAN}

\section{Implementasi Kebijakan SAPK, Perka BKN No. 20 Tahun 2008 Pemanfaatan SAPK di BKPSDM Kabupaten Fakfak}

Sistem Aplikasi Pelayanan Kepegawaian (SAPK) merupakan terobosan reformasi birokrasi dalam bidang pelayanan kepegawaian melalui penggunaan teknologi komunikasi dan informasi yang dikembangkan oleh Badan Kepegawaian Negara. Untuk menganalisis bagaimana Implementasi Kebijakan Perka BKN No. 20 Tahun 2008 di Kabupaten Fakfak Provinsi Papua Barat. Peneliti menggunakan Teori Edwards IIII, yang ditentukan oleh empat 
variabel meliputi komunikasi, sumber daya, disposisi dan struktur birokrasi.

\section{- Komunikasi}

BKN telah menyosialisasikan Peraturan Kepala BKN No. 20 Tahun 2008 dengan pemerintah kabupaten Fakfak dalam implementasi Peraturan tersebut sangatlah baik, dari hasil pengamatan peneliti tehadap Implementasi Kebijakan SAPK bahwa pengambil kebijakan dalam hal ini pejabat Pemerintah Kabupaten Fakfak sepenuhnya melakukan proses komunikasi yang baik yang pertama kejelasan dan pemahaman penggunaan SAPK serta konsistensi untuk tetap menggunakan dan mengaplikasikan dengan tujuan sistem informasi kepegawaian berbasis informasi teknologi yang terintegrasi sebagai media dalam pelayanan, pengawasan, pengendalian administrasi kepegawaian. Hal ini dapat dilihat dari sosialisasi dan pelatihan kepada admin dan user SAPK BKPSDM Kabupaten Fakfak.

\section{- Sumber Daya}

Informasi tentang proses implementasi kebijakan mungkintelah disampaikan dengan jelas dan konsisten tetapi jika pelaksana kekurangan sumber daya yang diperlukan untuk menyelesaikan implementasi kebijakan maka pengimplementasian suatu kebijakan tidak akan berjalan sesuai dengan apa yang diinginkan. Dalam pelaksanaan suatu program atau kebijakan tentu saja diperlukan pelaksana guna mendukung terlaksananya program atau kebijakan dengan baik. Tanpa adanya personel untuk melaksanakan suatu program atau kebijakan, maka program atau kebijakan apa pun tidak dapat berjalan dengan baik dan hanya akan tinggal sebagai dokumen tanpa ada realisasinya.

Selain jumlah pelaksana yang memadai juga diperlukan adanya pelaksana yang kompeten dalam menjalankan program tersebut, karena apabila jumlah pelaksana telah mencukupi, namun tanpa diimbangi dengan kemampuan atau keahlian dalam menjalankan program, maka dalam proses pelaksanaannya tidak dapat berjalan dengan maksimal. Ketersediaan sumber daya manusia yang terampil merupakan hal yang sangat penting agar pelaksanaan program atau kebijakan lebih efisien dan efektif, di mana kadangkala pelaksanaan suatu kegiatan terhambat selain karena jumlah pelaksana yang tidak memadai dan juga pada kurangnya kualitas sumber daya manusia sebagai pelaksana.

\section{- Disposisi}

Suatu kebijakan akan berhasil diimplementasikan jika para pelaksana kebijakan tidak hanya mengetahui regulasi yang ada, tetapi memahami apa yang harus mereka lakukan dan juga mempunyai kemampuan, serta kemauan dan sikap yang baik untuk mengimplementasikan kebijakan yang ada. Dua hal penting berkenaan dengan disposisi yaitu pengangkatan birokrasi, Dari pengangkatan birokrasi dalam hal ini staf pelaksana kebijakan SAPK di BKPSDM Kabupaten Fakfak telah ditetapkan dengan Tim SAPK. Selanjutnya setiap pihak memiliki komitmen yang kuat untuk melaksanakan tugas dengan baik dan penuh rasa tanggung jawab dengan diberikannya insentif berupa honor tiap bulannya.

\section{- Struktur Birokrasi}

Birokrasi merupakan salah satu institusi yang paling sering. Bahkan secara keseluruhan menjadi pelaksana kegiatan. Keberadaan birokrasi tidak hanya dalam struktur pemerintah, tetapi juga ada dalam organisasi-organisasi swasta, institusi pendidikan dan sebagainya. Bahkan dalam kasus-kasus tertentu birokrasi diciptakan untuk menjalankan suatu kebijakan tertentu. Ada dua karakteristik utama dari birokrasi yaitu Standard Operational Procedure (SOP) dan Fragmentasi. 
Tabel 3. Jumlah usulan kenaikan pangkat PNS dengan SAPK

Tahun 2017- 2020

\begin{tabular}{llcccc}
\hline No & $\begin{array}{l}\text { P e riode } \\
\text { kenaikan } \\
\text { pangkat }\end{array}$ & Tahun & $\begin{array}{c}\text { Usulan } \\
\text { (Kenpat) } \\
\text { periode } \\
\text { April dan } \\
\text { Oktober }\end{array}$ & $\begin{array}{c}\text { Usulan } \\
\text { (Kenpat) } \\
\text { Yang } \\
\text { disetujui }\end{array}$ & $\begin{array}{c}\text { Jumlah Usulan } \\
\text { yang tertunda } \\
\text { naik pangkat }\end{array}$ \\
\hline 1 & April & 2017 & 375 & 349 & 21 \\
& 2018 & 472 & 320 & 152 \\
& 2019 & 577 & 573 & 4 \\
\hline 2 & 2020 & 468 & 316 & 150 \\
\hline & 2017 & 258 & 254 & 4 \\
& 2018 & 253 & 253 & - \\
\hline
\end{tabular}

Sumber: BKPSDM Kabupaten Fakfak 2020

Struktur birokrasi dalam pelaksanaan kebijakan Sistem Aplikasi Pelayanan Kepegawaian dalam standar aplikasi pelayanan kepegawaian di BKPSDM Kabupaten Fakfak berpedoman pada buku juknisnya BKN. SOP yang digunakan haruslah mengacu pada Perka BKN 2008, dalam bentuk tata cara baku pelaksanaan, yang lebih dikenal dengan acuan untuk seluruh pelaksana kebijakan dalam bekerja.

\section{Faktor Pendukung dan Penghambat Implementasi Kebijakan SAPK di BKPSDM Kabupaten Fakfak}

Berdasarkan tabel 3 terlihat bahwa dari tahun 2017 sampai dengan tahun 2019 usulan kenaikan pangkat PNS Kabupaten Fakfak masih terdapat permasalahan yang cukup signifikan, di antaranya pada 2018 dan tahun 2020 jumlah PNS Kabupaten Fakfak dalam usulan kenaikan pangkat periode April mengalami permasalahan tertunda naik pangkat, hal ini dikarenakan berkas persyaratan dan pengimputan data PNS yang tidak valid untuk diusulkan ke BKN melalui SAPK.

\section{- Faktor Pendukung}

Dari hasil peneliti dan pengamatan yang peneliti dapatkan di lokasi penelitian, terkait dengan Implementasi kebijakan SAPK Guna mendorong implementasi kebijakan SAPK di Kabupaten Fakfak maka di antaranya dalam variabel Komunikasi terdapat dua faktor pendukung. Pertama Adanya penyampaian kebijakan secara tertulis melalui Surat Edaran Sekretaris Daerah dan penyampaian secara langsung pada saat pemberkasan hal ini dapat dilihat dalam penyampaian yaitu secara langsung pada saat pemberkasan kenaikan pangkat periode April dan Oktober, 2 bulan sebelumnya BKPSDM telah memberitahukan kepada seluruh perangkat daerah melalui surat edaran yang ditandatangani oleh Sekretaris Daerah untuk segera mengumpulkan persyaratan Kenaikan pangkat dalam pengimputan berkasnya melalui SAPK.

Kedua adalah ketersediaan sumber daya staf sebagai implementor yang cukup memadai, hal ini dikarenakan semua pegawai BKPSDM Kabupaten Fakfak dapat diberdayakan secara baik, maka dibutuhkan juga Sumber Daya Manusia (SDM) staf/ pegawai yang berkompetensi, memiliki keterampilan untuk membangun dan 
memanfaatkan SAPK sebagai teknologi informasi Kepegawaian. dalam pelaksanaan penerapan Implementasi Kebijakan SAPK di Kabupaten Fakfak secara efektif, efisien, transparan serta terintegrasi selanjutnya Kemampuan staf sebagai operator komputer dan pranata komputer cukup memadai dan pernah mengikuti pelatihan SAPK. Peningkatan Sumber Daya Manusia dalam meningkatkan dan mengembangkan potensi pegawai dengan diberikannya pendidikan baik formal maupun nonformal. Pendidikan nonformal seperti memberikan diklat-diklat, pelatihan serta kursus komputer, dengan Jumlah pegawai yang dimiliki oleh BKPSDM Kabupaten Fakfak adalah sebanyak 43 orang yang terdiri dari berbagai latar belakang pendidikan berbeda beda sudah cukup memadai dalam segala bidang khususnya di bidang SAPK.

Ketiga, semua bersikap menerima kebijakan SAPK dan melaksanakannya secara baik dan penuh tanggung jawab karena dapat mempercepat pelayanan kepegawaian dan adanya kesadaran bahwa pelayanan kepegawaian dengan menggunakan SAPK sudah merupakan Tupoksi masing bidang. Keempat Adanya Kejelasan prosedur pelaksanaan kebijakan SAPK yang telah diatur dalam Perka BKN No. 20 Tahun 2008 dan BKN telah Menyusun Buku Pedoman SAPK. Kelima Adanya kejelasan Pembagian Kewenangan antarpelaksana kebijakan yang satu dengan yang lainnya yang sudah diatur secara jelas dalam Tupoksi masing-masing bidang.

\section{- Faktor Penghambat}

\section{Komunikasi}

Faktor Penghambat Implementasi kebijakan SAPK di BKPSDM Kabupaten Fakfak dalam pengamatan yang peneliti dapatkan di lokasi penelitian, terdapat 3 (tiga) faktor di antaranya: pertama Tidak ada jaminan isi surat edaran tersebut sampai kepada seluruh PNS Perangkat
Daerah Dalam penyampaian informasi yang berkaitan dengan kepegawaian, BKPSDM Kabupaten Fakfak selalu memberikan pemberitahuan melalui surat edaran kepada Kasubag kepegawaian di masing-masing OPD, namun surat edaran tersebut kadang tidak sampai kepada seluruh ASN yang berada di lingkupnya, sehingga apabila ada pemberitahuan yang urgent/penting kadang kala tidak diketahui oleh ASN lain. kedua Para ASN di OPD yang lain jarang mendapatkan Informasi hal ini kemungkinan disebabkan karena pesan yang disampaikan ke daerah yang tidak terjangkau jaringan internet dan juga transportasi darat maupun laut. ketiga tidak ada jaminan isi surat edaran tersebut sampai kepada seluruh PNS di Perangkat Daerah dikarenakan jaringan internet dan juga transportasi sulit dijangkau.

\section{Sumber Daya}

Sumber daya dalam mengimplementasikan sebuah kebijakan merupakan salah satu faktor yang penting. Sumber daya dalam sebuah program/kebijakan tidak hanya sumber daya manusia saja, melainkan sarana dan prasarana juga merupakan faktor yang mendukung keberhasilan suatu program. Di samping sumber daya dan tujuan kebijakan yang menghambat proses implementasi kebijakan yang pertama Kemampuan staf sebagai tenaga analisis kepegawaian belum ada: hal ini disebabkan oleh tenaga analisis kepegawaian dalam memberikan pelayanan dengan SAPK dapat berjalan lancar walaupun hanya didukung dengan tenaga operator komputer dan pranata komputer, karena personel yang ada sudah pernah mengikuti pelatihan dan bintek SAPK. namun sudah ada staf yang ditugaskan untuk mengikuti diklat analis kepegawaian. 


\section{Disposisi}

Dalam kaitannya dengan Faktor Penghambat Implementasi kebijakan SAPK hasil penelitian yang didapatkan tiga hal berikut. Pertama, tidak semua implementor diangkat secara formal dan tergabung dalam Tim SAPK. Yang diangkat secara formal hanya implementor pelayanan peremajaan data pada bidang Informasi data dan kepegawaian selanjutnya.

Kedua, tidak semua implementor SAPK diberikan insentif, yang diberikan hanya yang termasuk dalam Tim SAPK. Kedua implementor yang menangani SAPK mempunyai komitmen dalam melaksanakan tugasnya ditunjuk dan diangkat secara formal melalui Keputusan Bupati tentang Pembentukan Tim SAPK.

Ketiga untuk memudahkan penggunaan pelayanan kepegawaian dalam Keberhasilan penerapan SAPK pada BKPSDM Kabupaten Fakfak sangat bergantung pada Konektivitas jaringan yang tersedia. dengan adanya dukungan konektivitas jaringan yang handal pada setiap bidang kepegawaian seperti peremajaan data SAPK yang dalam tiap tahunnya sering kali mengalami gangguan jaringan yang error pada saat pengoperasian proses pengentrian data sehingga memakan waktu yang cukup lama.

\section{Upaya-Upaya untuk Optimalisasi Implementasi Kebijakan SAPK di BKPSDM Kabupaten Fakfak}

1) Selama ini kebijakan SAPK disosialisasikan dalam bentuk surat edaran, agar lebih optimal ke depan akan dilakukan sosialisasi melalui forum khusus atau pertemuan sehingga bisa terjadi dialog interaktif terutama untuk OPD di kecamatan-kecamatan.
2) Bahwa PNS tenaga fungsional lebih banyak bertugas di kecamatankecamatan, sosialisasi dalam bentuk surat edaran seperti riya tidak cukup, perlu dilakukan sosialisasi dalam bentuk pertemuan atau tatap muka sehingga bisa terjadi tanya jawab tentang kebijakan SAPK.

3) User kenaikan pangkat dan pensiun perlu ditambah 1 orang menjadi 2 orang karena selama ini user yang ada kadang bekerja lembur sampai malam untuk menginput usulan kenaikan pangkat. Selain itu, sangat diperlukan adanya tenaga analis kepegawaian yang memverifikasi berkas sebelum diinput ke dalam SAPK.

\section{- Disposisi}

Kebijakan SAPK dalam pelayanan kepegawaian di Badan Kepegawaian dan Pengembangan SDM Kabupaten Fakfak selama ini dapat terlaksana berkat dukungan dan komitmen para pelaksana pada masingmasing bidang. Hal yang berkaitan dengan disposisi adalah pengangkatan birokrat secara formal dan pemberian insentif. Namun demikian tidak semua implementor yang mengoperasikan SAPK diangkat secara formal dan diberikan insentif, hal ini tentunya dapat menimbulkan ketidaksamaan sikap dalam melaksanakan program dan kebijakan. Berdasarkan hasil wawancara dengan para informan diketahui bahwa untuk menghindari kecemburuan, maka semua implementor sebaiknya diangkat secara formal sebagai anggota Tim dan juga diberikan insentif secara wajar.

\section{- Struktur Birokrasi}

Ruang lingkup kebijakan SAPK meliputi berbagai pelayanan sehingga terjadi penyebaran tanggung jawab. Untuk itu dibutuhkan kerja sama dan koordinasi yang baik. Dari hasil wawancara dengan para informan dapat diketahui bahwa koordinasi 
selama ini cukup berjalan dengan baik, akan tetapi hanya pada saat tertentu saja meliputi:

1) Koordinasi antarbidang informasi data dan kepegawaian terjadi apabila terdapat data PNS yang belum update pada aplikasi SAPK.

2) Koordinasi pengoperasian SAPK selama ini biasanya dilakukan apabila ada hal yang diperlukan, sebaiknya dilakukan secara rutin sehingga kerja sama dalam pemanfaatan SAPK lebih optimal.

\section{SIMPULAN}

Berdasarkan keseluruhan hasil penelitian dan hasil analisis yang telah diuraikan, untuk menjawab rumusan masalah penulis menarik simpulan sebagai berikut.

1. Implementasi Kebijakan Perka BKN No. 20 Tahun 2008, Pemanfaatan SAPK di BKPSDM Kabupaten Fakfak

Implementasi kebijakan Perka BKN No. 20 Tahun 2008 Pemanfaatan SAPK di BKPSDM Kabupaten Fakfak sudah dilaksanakan sesuai dengan Peraturan Kepala Badan Kepegawaian Negara No. 20 Tahun 2008 tentang Pedoman Pemanfaatan Sistem Aplikasi Pelayanan Kepegawaian, baik dalam proses pengadaan, kenaikan pangkat, pensiun dan peremajaan data. Diharapkan BKPSDM ke depan dengan adanya kebijakan pemanfaatan SAPK sebagai proses pelayanan kepegawaian pada Badan Kepegawaian dan Pengembangan SDM Kabupaten Fakfak dapat terlaksana secara lebih efektif dan efisien.

2. Faktor Pendukung Implementasi Kebijakan SAPK di BKPSDM Kabupaten Fakfak

Terdapat empat faktor yang mendorong Implementasi Kebijakan SAPK di BKPSDM Kabupaten Fakfak meliputi:

\section{a. Faktor Komunikasi}

1) Adanya penyampaian kebijakan secara tertulis melalui Surat Edaran Sekretaris Daerah dan penyampaian secara langsung pada saat pemberkasan;

2) Adanya kejelasan dan konsistensi dalam penyampaian pesan dengan berpedoman pada aturan yang dalam pelaksanaan kebijakan SAPK dalam pelayanan kepegawaian.

\section{b. Faktor Sumber Daya}

1) Ketersediaan sumber daya staf sebagai implementor cukup memadai karena semua dapat diberdayakan apabila dibutuhkan;

2) Kemampuan staf sebagai operator komputer dan pranata komputer cukup memadai dan pernah mengikuti pelatihan SAPK.

\section{c. Faktor Disposisi}

- Semuabersikapmenerimakebijakan SAPK dan melaksanakannya secara baik dan penuh tanggung jawab karena dapat mempercepat pelayanan kepegawaian dan adanya kesadaran bahwa pelayanan kepegawaian dengan menggunakan SAPK sudah merupakan Tupoksi masing bidang.

\section{d. Faktor Struktur Birokrasi}

1) Adanya Kejelasan prosedur pelaksanaan kebijakan SAPK yang telah diatur dalam Perka BKN No. 20 Tahun 2008 dan BKN telah Menyusun Buku Pedoman SAPK.

2) Adanya kejelasan Pembagian Kewenangan antarpelaksana kebijakan yang satu dengan yang lainnya yang sudah diatur secara jelas dalam Tupoksi masing-masing bidang. 
Faktor Penghambat Implementasi Kebijakan SAPK di BKPSDM Kabupaten Fakfak

\section{a. Faktor Sumber Daya}

1) Tidak ada jaminan isi surat edaran tersebut sampai kepada seluruh PNS di OPD.

2) Kemampuan staf sebagai tenaga analisis kepegawaian yang memeriksa keabsahan berkas yang akan di input pada SAPK belum ada;

3) Jaringan konektivitas untuk mengakses data SAPK sering mengalami gangguan;

4) Keterbatasan sarana fisik (ruangan kantor sangat kecil dan terbatas. Dan tidak representatif);

\section{b. Faktor Disposisi:}

1) Tidak semua implementor diangkat secara formal dan tergabung dalam Tim SAPK. Yang diangkat secara formal hanya implementor pelayanan peremajaan data pada bidang Informasi data dan Kepegawaian;

2) Tidak semua implementor SAPK diberikan insentif, yang diberikan hanya yang termasuk dalam Tim SAPK.

3. Upaya Optimalisasi Implementasi Kebijakan SAPK di BKPSDM Kabupaten Fakfak

a) Sosialisasi berupa rapat khusus, pertemuan ataupun tatap muka langsung sehingga bisa tercipta tanya jawab dan dialog interaktif terutama di kecamatan;

b) Mengikutsertakan staf diklat analisis kepegawaian sebagai syarat untuk pengangkatan tenaga analis kepegawaian;

c) Semua personel yang mengoperasikan SAPK dalam pelayanan kepegawaian diangkat secara formal sebagai Tim dan diberikan insentif.

\section{SARAN}

Berdasarkansimpulandanhasilpenelitian yang telah dikemukakan di atas, maka dapat diberikan saran yang nantinya diharapkan dapat menyempurnakan implementasi kebijakan pemerintah dalam pelayanan kepegawaian dengan menggunakan SAPK pada Badan Kepegawaian dan Pengembangan SDM (BKPSDM) Kabupaten Fakfak sebagai berikut.

1) Implementor kebijakan SAPK yang memiliki kemampuan atau kompetensi sebagai analisis kepegawaian perlu segera mengangkat agar berkas usulan yang diinput dalam SAPK memiliki keabsahan sesuai yang dipersyaratkan;

2) Melakukan koordinasi dengan PT Telkom untuk segera memperbaiki kerusakan jaringan VPN/IP yang telah terpasang sehingga konektivitas untuk mengakses SAPK tidak mengalami hambatan;

3) Agar tidak menimbulkan kecemburuan yang bisa berdampak pada menurunnya implementor dalam melakukan pelayanan, maka semua implementor harus diangkat secara formal sebagai Tim SAPK dan diberikan insentif secara wajar;

4) Badan Kepegawaian dan Pengembangan SDM Kabupaten Fakfak merekrut pegawai yang berlatar pendidikan komputer atau mengikutkan pegawai yang mempunyai potensi dan minat pada bidang pengembangan teknologi informasi.

5) Penambahan Perangkat keras Komputer: CPU dan Printer baru untuk mendukung serta mengoptimalkan SAPK secara efektif dan efisien.

6) Penambahan User SAPK di tiap-tiap bidang BKPSDM Kabupaten Fakfak yang di-update oleh Admin SAPK, guna kelancaran proses pemanfaatan sistem SAPK agar lebih optimal. 


\section{DAFTAR RUJUKAN}

Agustino, Leo. 2014. Dasar-dasar Kebijakan Publik. Bandung: Alfabeta

2010. Prosedur Penelitian Suatu Pendekatan Praktik. Jakarta: Rineka Cipta.

A Qodri Azizi, 2004, Membangun Fondasi Ekonomi Umat. Yogyakarta: Pustaka Pelajar.

Anggara, Sahya. 2014 Kebijakan Publik. Bandung: Pustaka Setia

Arikunto, Suharsimi. 2006. Prosedur Penelitian Suatu Pendekatan Praktik. Jakarta: Rineka Cipta,

Asyari, Sapari Imam. 1983. Metodologi Penelitian Sosial: Suatu Petunjuk Ringkas. Surabaya: Usaha Nasional.

Budi Wiharmo, 2012. Kebijakan Publik (Teori Proses dan Studi Kasus), Jakarta:

Edwards III, 1980 Implementation Public Policiy. Washington DC: Congresional Quarter Press

Haryanto dkk, 1997. Pemerintah. Jakarta. Rineka Cipta

Heeks, Richrad. 2006 Implementing and managing e-goveernment. Sage London

I Nyoman Sumaryadi, Efektivitas Implementasi Kebijakan Otonomi Daerah, Jakarta: Citra Utama, 2005.

Irawan. Prasetya. 2004. Logika dan Prosedur Penelitian: Pengantar Teori dan Panduan Praktis Penelitian Sosial bagi Mahasiswa dan Peneliti Pemula. Jakarta: STIA LAN Press

James E. Anderson Indiahono 2009., Kebijakan Publik Berbasis Dynamic Policy Analysis, Yogyakarta: Pustaka Pelajar.

Masyhuri, M. Zainuddin. 2008. Metode Penelitian Pendekatan Praktis dan Aplikatif. Bandung: PT Refika Aditama

Meriles S. Grindle, Politics and Policy Implementation in The Third World. Princeton, (New Jersey: Princeton University Press, 1980).

Moenir, 2005, Manajemen Pelayanan Umum di Indonesia, Bumi Aksara Jakarta

Moh Nazir. 2011. Metode Penelitian. Jakarta: Ghalia Indonesia.

2011. Metode Penelitian. Cetakan 6. Bogor: Penerbit Ghalia Indonesia,
Moleong, L.J. 2011. Metodologi Penelitian Kualitatif Edisi. Revisi. Bandung: PT Remaja Rosdakarya,

Nazir. Moh. 1989. Metode Penelitian Sosial. Jakarta: PT Bina Aksara 2009. Metode Penelitian. Jakarta: Ghalia Indonesia

Nurcholis, Enceng dan Amin (2010). Administrasi Pemerintahan Daerah Jakarta. Universitas Terbuka

Riduwan. 2004. Metode dan Teknik Menyusun Tesis. Bandung: Alfabeta,

Samoedra Wibawa, 1994 Implementasi Kebijakan Publik, Jakarta: Balai Pustaka,

Straus Anslem dan Juliet Corbin. 2007. DasarDasar Penelitian Kualitatif. Yogyakarta: Pustaka Belajar Offset.

2014, Metode Penelitian Pendidikan: Pendekatan Kuantitatif, Kualitatif dan $R \& D$, Bandung: Alfabeta

S. E. Finer, 1974 Comparative Government, Penguin Books Ltd,. Hartmonds Worth, Middlesex, England

Solichin Abdul Wahab, 2001, Analisis Kebijakan dari Formulasi ke Penyusunan Modelmodel Implementasi Kebijakan Publik, Jakarta: Bumi Aksara.

2004. Analisis Kebijakan dan Formulasi ke Implementasi Kebijakan Negara, Jakarta: Bumi Aksara, 2008. Pengantar Analisis Kebijakan Publik, Malang: UMM Press.

Sutarman 2009. Pengantar teknologi Informasi. Jakarta:Bumi Aksara*

Tachjan, 2006 Implementasi Kebijakan Publik, Bandung: AIPI

Uber Silalahi, 2012. Metode Penelitian Sosial, Refika Aditama, Bandung,

Winarno, Budi. Kebijakan Publik: Teori, Proses, dan Studi Kasus; Yogyakarta; Center of Academic Publishing Service (CAPS). 2014.

Zuriah Nuzul, 2009, Metodologi Penelitian Sosial Pendidikan Teori-Aplikasi, Jakarta: PT Bumi Aksara 